\section{Oil price fluctuations and economic growth: the case of MENA countries}

\author{
Mamdouh Abdelmoula Mohamed Abdelsalam \\ Department of Economics, Minufiya University, Shebin El-Kom, Egypt
}

\begin{abstract}
Purpose - This paper aims to explore the extreme effect of crude oil price fluctuations and its volatility on the economic growth of Middle East and North Africa (MENA) countries. It also investigates the asymmetric and dynamic relationship between oil price and economic growth. Further, a separate analysis for each MENA oil-export and oil-import countries is conducted. Furthermore, it studies to what extent the quality of institutions will change the effect of oil price fluctuations on economic growth.

Design/methodology/approach - As the effect of oil price fluctuations is not the same over different business cycles or oil price levels, the paper uses a panel quantile regression approach with other linear models such as fixed effects, random effects and panel generalized method of moments. The panel quantile methodology is an extension of traditional linear models and it has the advantage of exploring the relationship over the different quantiles of the whole distribution.

Findings - The paper can summarize results as following: changes in oil price and its volatility have an opposite effect for each oil-export and oil-import countries; for the former, changes in oil prices have a positive impact but the volatility a negative effect. While for the latter, changes in oil prices have a negative effect but volatility a positive effect. Further, the impact of oil price changes and their uncertainty are different across different quantiles. Furthermore, there is evidence about the asymmetric effect of the oil price changes on economic growth. Finally, accounting for institutional quality led to a reduction in the impact of oil price changes on economic growth.
\end{abstract}

Originality/value - The study concludes more detailed results on the impact of oil prices on gross domestic product growth. Thus, it can be used as a decision-support tool for policymakers.

Keywords Economic growth, Crude oil price, Asymmetric effect, Extreme effect, Panel quantile regression

Paper type Research paper

\section{Introduction}

Energy plays the most critical role in the global economy. Despite the increasing debate around the role of alternate renewable sources of energy such as water, solar and nuclear power, oil still has a central role for a vast portion of the world's countries. Hence, oil price shocks might have considerable macroeconomic consequences for both importing and exporting countries. As for the former category, oil is a major determinant of production cost and for the latter, it is the primary source of government revenue. Further, fluctuations in oil

(C) Mamdouh Abdelmoula Mohamed Abdelsalam. Published in Review of Economics and Political Science. Published by Emerald Publishing Limited. This article is published under the Creative Commons Attribution (CC BY 4.0) licence. Anyone may reproduce, distribute, translate and create derivative works of this article (for both commercial and non-commercial purposes), subject to full attribution to the original publication and authors. The full terms of this licence maybe seen at http:// creativecommons.org/licences/by/4.0/legalcode

JEL classification - E32, Q43, C3

\section{Oil price fluctuations and economic growth}

Received 21 December 2019

Revised 7 September 2020 26 October 2020

Accepted 27 October 2020 
prices affect production costs, heating bills and transportation costs. This generates uncertainty about the future of the world economy. This may also encourage investors to delay their producing decisions and reallocate labor and capital from intensive petroleum sectors to non-intensive petroleum sectors (Sill, 2007). It is argued that oil price fluctuations have caused instability of many macroeconomic aggregates in both oil-exporters and importers countries (Brinin et al., 2016). Consequently, because of this double importance of oil, it has been argued that its price is highly volatile than that of any other commodity and it is almost unpredictable (Dehn, 2001).

However, the effect of changes in the oil price is different for exporting and importing countries. Exporting countries massively depend on oil revenue. Then, a rise in oil prices means increasing the amount of money available for funding development projects. Therefore, monetary and fiscal policies function is considerably affected by oil price fluctuations (Saddiqui et al.,2018). However, the adverse effect makes the financial and real aggregates more uncertain due to the oil price volatility, particularly in the case of imperfect capital markets (Hausmann and Rigobon, 2003). On the contrary, when the oil price is falling, governments cannot immediately cut their expenditures and then face a massive budget deficit. As changes in oil prices have a considerable effect on macroeconomic performance in both exporting and importing countries, analyzing this effect and predicting to what extent gross domestic product (GDP) in different countries is sensitive to these variations are crucial

However, the dependence between oil price and economic growth is not the same over different business cycles or oil price levels (Kilian and Vigfusson, 2011; Das et al., 2018). Therefore, this study explores the extreme dependence between oil price fluctuations and economic growth in Middle East and North Africa (MENA) countries using quantile regression (Q.R.) in addition to the other four linear models. To our knowledge, there are no studies that explored the extreme effect of the oil prices on the economic growth of MENA countries. Q.R.'s approach was presented by Koenker and Bassett (1978). It targets the assessment of the underlying relationship based on each quantile $\tau$ (Baur, 2013). Unlike the ordinary least squares (OLS) and other traditional models, which assess the effect of the explanatory variable on the dependent variable on average. The Q.R. methodology is an extension of traditional linear models and it has the advantage of exploring the whole relationship about the impact of oil price changes on economic growth. Further, oil price changes are characterized by heavy tails and sharp peaks. As quantile regression is robust to skewness, kurtosis and heteroscedasticity, Q.R. can be used to overcome these phenomena (Koenker, 2004; Chuang et al., 2009; Lin, 2013; Mensi et al., 2014). The study aims at exploring how economic growth is affected by the fluctuations and the volatility of crude oil prices, as well as the asymmetry of crude oil price changes in the MENA region. In addition, it investigates how augmenting the quality of institutions will affect the previous relationship. Thus, the paper tries to answer the following four questions: what the expected extreme effect of the fluctuations in crude oil prices on different MENA countries? How do the changes in oil price and volatility of oil price impact the MENA economies? To what extent should changes in oil price and oil price volatility be taken into consideration when estimating or forecasting the economic growth of MENA countries? (4) Does the existence of more qualified and effective institutions affect the relationship between oil price fluctuations and GDP growth?

This paper contributes to previous studies in different aspects. First, it explores the extreme impact of both oil price and uncertainty of oil price on the real product; to our knowledge, no previous study considered this point before. Second, it explores to what extent the effect of oil prices is asymmetric. The analysis of this paper is used as a decision- 
support tool for policymakers as it attempts to investigate to what extent oil prices and oil prices volatility should be taken into consideration when calculating and predicting economic growth. All four linear models give robust analysis such as that: changes in oil price fluctuations have a significant positive impact on economic growth while the volatility of oil price has an insignificant positive effect. In addition, there is evidence about the asymmetric effect of oil price changes on economic growth. Further, Q.R. emphasizes the importance of analyzing the extreme effect of oil price changes and uncertainty of oil price on economic growth as the effect of those variables is more significant in upper quantiles than middle or lower ones. Furthermore, the quality of institutions has a significant positive effect on GDP growth. Also, augmenting the quality of institutions in the analysis resulted in lowering the impact of crude oil changes on economic growth, and the effect of the volatility becomes insignificant in all models. Moreover, a separate analysis for each MENA oil-export country and MENA oil-import countries is conducted and results show that for oil-export countries, changes in oil prices have a significant positive impact but the volatility has a negative effect. Whereas for oil import countries, changes in oil prices have a significant negative effect but volatility a positive significant effect. This paper is structured as follows. Section 2 highlights the relative existing literature. Section 3 illustrates the methodology and empirical analysis. Section 4 presents the data and empirical results. Finally, in Section 5 the conclusion and policy recommendations are provided.

\section{Literature review}

The relationship between oil price and economic growth has attracted many researchers after the pioneering work of Hamilton (1983), who concludes that there is a negative effect of oil price on the real product. In this instance, it is argued that oil price fluctuations have a considerable impact on individuals' welfare over the globe (Mgbame et al., 2015). However, other works claim that the actions of economic policies can absorb the effect of oil price shocks on the real product (Vespignani et al., 2019; Gershon et al., 2019). Further, Odhiambo (2020) reviews the literature about the effect of oil price fluctuations on economic growth and he states that the effect varies for different countries or different samples.

There is a continuous debate in the literature about the direction of oil price effect on economic growth. Whereas some studies argue that for exporting countries, oil price increases lead to enhancing the level of income and then consequently both investment and consumption incomes grow, which means higher levels of GDP growth; indeed, higher oil prices lead to higher earnings, which imply higher incomes in oil-exporting-nations (Akpan,2009; Foudeh,2017; Jahangir and Dural, 2018; Dabachi et al., 2020). However, some empirical studies conclude that there is a negative effect of oil price changes on GDP growth, particularly in importing countries where the oil price is considered one of the most critical factors of production (Arouri and Nguyen, 2010; Filis et al., 2011; Murshed and Tanha, 2020; Rahman and Majumder,2020). According to this view, a rise in world oil prices lowers incomes for oil-importing countries. In this regard, this reduction in income depends on the degree of oil price elasticity and the persistent change in the oil price (Ghalayini, 2011). Further, central banks might adopt contradictory policies to lessen the domestic price increases and this also brings more restrictions on the real production side. Papapetrou (2001) and Miguel et al. (2003) found a negative effect of changes in oil prices on GDP growth in Greece and Spain, respectively. Bouzid (2012) explored the Tunisian case and concluded that a $10 \%$ higher increase in the global oil price causes a 3.4\% decline in GDP growth.

The volatility of oil prices is also given considerable attention in the literature. Okonju (2009) argued that oil prices have higher volatility more than any other products, which brings undesirables negative impacts on the real product side. Amany El-Anshasy et al. 
(2017) conclude that the volatility of oil revenue has a significant negative impact on GDP growth. However, this effect becomes less with the existence of mature institutions as a more qualified fiscal regime. Van Eyden et al. (2019) found a significant negative effect on oil price volatility on GDP growth. However, other studies confirmed a positive impact on oil price volatility on GDP growth such as Bjornland (2000) for Norway economy and Akinlo and Tolulope Apanisile (2010) for 20 Sub-Saharan African countries. In addition, Cavalcanti et al. (2015) explore the effect of volatility and level of the commodity of trade terms on GDP and they conclude that volatility is the main determinant for the "resource curse." Some studies found the effect of oil price volatility can be moderated; for example, Jarrett et al. (2018) found that the financial institutions can decline the possible impacts of oil price volatility on some oil-producing countries.

The asymmetric effect of oil price on economic growth, whether positive and negative oil price shocks have different impacts is another important topic for recent literature. The likely asymmetric effect of oil price could be justified using three justifications: uncertainty, sectoral effects and counter inflationary monetary actions (Kilian and Vigfusson, 2011; Raheem,2017; Akinsola and Nicholas, 2020). For instance, Hamilton (2008) argues that oil price shocks might push customers in intensive energy sectors to reduce their demands while other sectors which do not intensively depend on energy might be more costly to pay the cost of shifting of labor and capital inputs across sectors due to training costs and other mobility costs. Studies such as (Hamilton, 2003) conclude that positive changes in world oil prices have a stronger effect on economic performance than negative ones. JiménezRodríguez and Sanchez (2005) find rising in the oil price has more effect on GDP growth than its fall in the selected The Organisation for Economic Co-operation and Development (OECD) countries. Similarly, Maalel and Mahmood (2018) find oil price shocks have an asymmetric impact on The Gulf Cooperation Council (GCC) economies.

Although the main body of the literature considered the case of developed economies, other works explore the case of emerging and developing countries. For instance, Anashasy et al. (2005) find a significant association between oil price fluctuations and some economic aggregates for Venezuela such as GDP, government revenues, government consumption and investment. Farzanegan and Markwardt (2009) studied the effect for Iran; Gbatu et al. (2017) for Liberia; Kousar et al. (2019) for Pakistan and Widarjono et al. (2020) for Indonesia. Other studies such as Saban et al. (2019) compared different countries by exploring the effect for each country individually. Regarding the MENA countries; Mehrara and Oskui (2007) provide evidence that oil price fluctuations are the primary source of instability of the macroeconomic aggregates in Saudi Arabis. Berument et al. (2010) conclude that the impact of changes in oil price on economic growth is significant for some MENA countries while it is insignificant for others. Selim and Zaki (2014) find that institutional quality is a leading cause of resource curse in Arabian countries. Cashin et al. (2016) used a global vector autoregression (GVAR) model to estimate the expected effects of macroeconomic shocks in the main economies (US, Europe and China) on the MENA economies. They conclude that shocks in the Chinese economy have a considerable influence on MENA countries. Mahmood and Zamil (2019) conclude fluctuations in oil prices have a considerable effect on Saudi Arabia GDP via the effect on the budget deficit. Similar results are concluded for GCC countries by Vohra (2017) and for Bahrain by Abou Elseoud and Kreishan (2020).

\section{Model and methodology}

The paper aims at examining the impact of changes in oil prices and their volatilities on the GDP of the MENA countries. Further, it explores how the inclusion of institutional quality can affect this relationship. The study uses the base model for Mankiw et al. (1992), given 
that it allows augmenting other variables such as the human capital and institutional quality inside the traditional classic model for Solow (1956). The model can be formulated as follows:

$$
Y_{i t}=A_{0} H_{i t}^{\beta} G F C_{i t}^{\alpha} A L D_{i t}^{\delta}
$$

Where, $Y_{i t}$ represents the real GDP growth for country $\mathrm{i}$ in the year; $A_{0}$ represents a scaling coefficient; and $H_{i t}, G F C_{i t}$, and $A L D_{i t}$ embody human capital, physical capital and land, respectively. The above equation represents a Cobb-Douglas production function, which can be transformed into a log-linear equation. With augmenting other variables can, equation (1) can be rewritten as follows:

$$
\begin{aligned}
Y_{i t}= & \beta_{0}+C O P_{t}+V C O P_{t}+D_{t}+\beta \ln \left(H_{i t}\right)+\alpha \ln \left(G F C_{i t}\right)+\delta \ln \left(A L D_{i t}\right)+X_{i t} \\
& +\varepsilon_{i t}
\end{aligned}
$$

In more details can be written as follows:

$$
\begin{aligned}
Y_{i t}= & \beta_{0}+\varrho C O P_{t}+\tau V_{C O P}+\varphi \mathrm{As}_{\mathrm{D}} \mathrm{um}_{t}+\beta \ln \left(H_{i t}\right)+\alpha \ln \left(G F C_{i t}\right)+\delta \ln \left(A L D_{i t}\right) \\
& +\vartheta X_{i t}+\varepsilon_{i t}
\end{aligned}
$$

Where, $Y_{i t}$ is the growth in the real domestic product (GDP); $C O P_{t}$ is the change in Crude oil prices; $V C O P_{t}$ is the volatility of crude oil prices; and $\mathrm{As}_{\mathrm{D}} \mathrm{um}_{t}$ represents the dummy variable that captures the asymmetry in the underlying relation (i.e. whether the changes in oil prices are positive or negative). The secondary enrollment percentage ( $\left.S S E_{i t}\right)$ and population growth $\left(P G_{i t}\right)$ are used to approximate the human capital. Whereas the value of a real investment in order approximate the physical capital $\left(G F C_{i t}\right)$, Arable land in hectares $\left(A L D_{i t}\right)$. In addition, $X_{i t}$ is the included control variables, which include the initial $I L G D P_{i t}$ (initial GDP) to control for the likely conditional convergence, $E R D_{i t}$ represents the exchange rate deviation from the longrun exchange rate level. Further, net exports to GDP $\left(E P G_{i t}\right)$ is used to examine the extent to which real output growth is affected by trade openness. Furthermore, OED is a dummy variable which takes 1 for oil export countries and 0 for other import countries and finally, $I N S_{i t}$ is used to account for the institution's quality index. In the case of the dynamic panel approach, $X_{i t}$ also includes the lag of the dependent variable $\left(Y_{i t-1}\right)$.

To be involved in the ongoing debate around the effect of oil price uncertainty on different economic activities, we will use an approximation of the variability of crude oil prices. The conditional variance of oil price shocks is calculated by using a generalized autoregressive conditional heteroskedasticity $(\mathrm{GARCH})$ model which is based on monthlydata for the oil price. Then, the annual conditional volatility is captured by taking the average of the 12 -month volatility.

The effect of oil price changes, the volatility of oil price and the asymmetric effect of oil price on economic growth are explored based on the specification of equation (3). The coefficients of the equation (3) are estimated using four different linear approaches: Pooled OLS, Fixed effect estimation, Random effect estimation and generalized method of moments (GMM). Further, to account for the whole distribution of the relationship, we also use the panel quantile approach. 
Regarding linear models, pooled OLS does not account for heterogeneity between the cross-sections in the model, while the fixed-effect approach and the random effect approach consider heterogeneity between cross-sections. However, all the previous three approaches ignore the endogeneity problem when adding the lag of the dependent variable.

The system of the GMM method overcomes the likely endogeneity problem that comes from augmenting the lag of the dependent variable inside the explanatory variable. The system GMM method depends on adding lags of independent variables as instruments. The estimation based on GMM has the advantages that it gives a consistent estimation for coefficients with an asymptotically normal distribution (Ziliak, 1997). The system GMM is widely used and is heavily recommended in the growth literature. Bond et al. (2001) and Hauk and Wacziarg (2009) state that the GMM approach is preferred for growth models to get consistent and efficient coefficients.

Q.R. is initially innovated by Koenker and Basset (1978), and it acts as the general form of Ordinary Least Squares (OLS); it provides more precise estimates of the conditional distribution. Q.R. approach assumes that the value of the error term is conditional on the included explanatory variables at $\tau$ th quantile equal to 0 . Thus, the Q.R. for y as a dependent variable and $\mathrm{x}$ as an independent variable can be represented in the following form:

$$
Q_{y \mid x}(\tau)=\inf \left\{b \mid F_{y \mid x}(b) \geq \tau\right\}=x^{\prime} \beta(\tau)
$$

Where $Q_{y \mid x}(\tau)$ denotes the conditional quantile of the dependent variable y, $0<\tau<1$ and $\beta(\tau)$ is the degree of effect of $\mathrm{x}$ on $\mathrm{y}$ in the $\tau$ th quantile which can be estimated as:

$$
\hat{\beta}(\tau)=\operatorname{argmin}_{\beta(\tau)} \sum_{i=1}^{n} \rho_{\tau}\left(y_{i}-x^{\prime} \beta(\tau)\right)
$$

If $\varepsilon_{i}$ is the random error term, thus the loss function for the quantile regression can be written as follows:

$$
\rho_{\tau}\left(\varepsilon_{i}\right)=\varepsilon_{i}\left[\tau-I\left(\varepsilon_{i}<0\right)\right]
$$

Where I(.) denotes the indicator function and $\rho_{\tau}\left(\varepsilon_{i}\right)$ denotes the check function which weighs in an asymmetric way the negative and positive values.

To check for the assumption of symmetry, we use Newey and Powell (1987) test. If the distribution of $\mathrm{Y}$ based on $\mathrm{X}$ is symmetric, then:

$$
\frac{\beta(\tau)+\beta(1-\tau)}{2}=\beta\left(\frac{1}{2}\right)
$$

Thus, we can use the Wald test on the quantile process to evaluate the previous restriction. If we assume we have an odd number, K, of a set of estimated parameters which ordered $\tau_{k}$, then the middle value which $\left(\tau_{k+1}\right) / 2$ should be 0.5 . Thus, the underlying function is symmetric around 0.5 , and the assumed null hypothesis is as follows:

$$
\frac{\theta\left(\tau_{j}\right)+\theta\left(\tau_{k-j-1}\right)}{2}=\theta(1 / 2) \text { for } j=1, \ldots, \frac{K-1}{2}
$$


The Wald test is designed with the null hypothesis of the symmetric effect, and it follows $\chi_{\rho(K-1) / 2}^{2}$. Indeed, refusing the null hypothesis of Newey and Powell (1987) test means refusing the assumption of symmetric values of the relationship over different quantiles.

Regarding the generating of oil price volatility, as it is mentioned before, it will be captured based on the GARCH model. The initial form of GARCH was introduced by Bollerslev in 1986. In the context of the previous model, the mean equation will be modeled as a function in its lags. In addition, the conditional variance is a function in the lag of squared residuals and the lag of the conditional variance. If we assume that the conditional variance is $h_{t}$ and the squared errors is $\varepsilon_{\mathrm{t}}^{2}$, then we can express the $\operatorname{GARCH}(1,1)$ representation as follows:

$$
h_{t}=\lambda_{0}+\lambda_{1} \varepsilon_{t-1}^{2}+\lambda_{2} h_{t-1}
$$

The coefficient $\lambda_{2}$ measures the persistence inside the conditional variance equation which implies that when $\lambda_{2}$ is close to 0 , the persistence is lower whereas the persistence is higher when $\lambda_{2}$ close to one. Further, the variance should be strictly positive, and the coefficients must not be negative; $\lambda_{0} \geq 0, \quad \lambda_{1} \geq 0, \quad \lambda_{2} \geq 0$. Furthermore, the stationarity condition should be valid for the conditional volatility equation; $\left(\lambda_{1}+\lambda_{2}<1\right)$.

\section{Data, descriptive analysis and results 4.1 Data}

The study uses annual data of a panel of 17 MENA countries, which include: Algeria, Bahrain, Egypt, Israel, Jordan, Kuwait, Lebanon, Libya, Morocco, Oman, Qatar, Saudi Arabia, Sudan, Tunisia, Turkey, United Arab Emirates and Yemen. The sample span covers the period (1970-2018) to capture the surge in oil prices in the 1970s. The data set includes the growth in the Real Gross Domestic Product (constant 2010 USD), Crude oil price, the secondary school enrollment percentage, the population growth percentage, gross fixed capital formation (constant 2010 US\$), arable land in hectares, the exchange rate deviation from the long-run exchange rate level calculated as the deviation from the longrun trend which estimated by "Hodrick-Prescott Filter method," net exports to GDP (the exports of goods and services minus imports of goods and services as a percentage of GDP). The institution quality index embodies the average of the sub-indices such as government stability, socioeconomic conditions, investment profile, internal conflict, external conflict, corruption, military intervention in politics, religious tensions, law and order enforcement, ethnic tensions, democratic accountability and bureaucracy quality. The data for the variables are captured from the world bank database. Further, the data of the crude oil price is represented by the West Texas Intermediate (WTI) crude oil spot prices, which are collected from the International Energy Agency. Finally, data about institution quality are captured from "Political Risk Services Group databases." All regression variables are implemented with logs of the variables.

\subsection{Descriptive analysis}

Figure A1 depicts the development of the index of crude oil price. As shown in the figure, the oil price is highly volatile during the period of the study. Thus, there was a significant increase in oil prices starting from 1973 due to the political pressure and war in the MENA region. However, with the 1980s and the economic slowdown in many developed countries, the oil demand dropped again. The price tended to increase from the beginning of the $2000 \mathrm{~s}$ 
until the last global crisis in 2008. Another episode of oil price increases started after the recovery of the financial crisis until starting to fall in 2014.

Table A1 displays the descriptive statistics for the included variables in the panel form. For more details, analysis for each oil-export and oil-import is going to be separated. Table A2 shows the correlation matrix for MENA exporting countries. As shown in the table, there is a positive correlation between GDP growth on one side and crude oil price changes, institutional quality, Secondary school enrolment percentage and population growth on the other side. In contrast, the correlation between GDP growth and oil price volatility is negative.

Figure A2 shows the evolution of crude oil prices and GDP growth for the MENA oilexporting countries. It could be observed that there is a positive association between both variables. However, the linkage between both variables was stronger for most oil-exporting countries at the beginning of the sample: then, it has been weakened in the past 10 years. This could be explained by the economic diversification strategy that has been applied in many oil-exporting countries such as Saudi Arabia and Emirates. On the other hand, the relation between oil price volatility and GDP growth for MENA oil-exporting countries is negative for long periods and many countries are depicted in Figure A3.

Table A3 shows the correlation matrix for the MENA oil-importing countries. It can be observed that the GDP growth is negatively correlated with crude oil price changes and population growth. While it is positively correlated with the volatility of crude oil price, the institution quality and percentage number of secondary schooling. The evolution of both crude oil prices and GDP growth rates for oil-importing nations in the MENA region is presented in Figure A4, where it can be observed that a negative association between the two variables. In addition, Figure A5 depicts the evolution of oil volatility and GDP growth in the oil-importing countries in the MENA regions, where it can be observed it is slightly positive for some countries.

\subsection{Results}

To check for stationarity of the included variables, The Phillip Perron (PP) test and the Augmented Dickey-Fuller (ADF) tests are applied. Table A4 depicts the results of these unit root tests. As shown in the table, the probabilities of the two used tests indicate that we should reject the null hypothesis of the unit root for all the used variables.

Table A5 reveals the results of the GARCH model. It shows that in the mean equation both the first leg and the second lag are significant. In the variance equation, both the squared of previous residual and lag of the GARCH are significant. Also, the summation of the last two coefficients is less than one, which is a required assumption for the stationarity of the GARCH model. Figure A6 plots the volatility of oil prices over the period under study.

Table A6 shows the estimates using the pooled OLS, fixed effect, random effect and the system GMM, respectively. According to the results of the pooled OLS model, changes in oil prices have a significant positive effect on output growth whereas volatility of oil price has a positive effect but insignificant. In addition, the dummy variable for the asymmetric effect of oil price changes is significant and positive. Further, capital formation percentage has a significant and positive effect, population growth has a negative and significant effect and the dummy variable for oil-exporting countries has a significant positive effect.

Regarding the results of the fixed effect method, Table A6 shows changes in oil prices have a significant positive effect whereas the volatility of oil price has an insignificant positive effect. Further, there is evidence that the effect of oil price changes on economic growth is asymmetric and the population growth has a negative significant effect. However, the exchange rate deviation does not have a significant effect on output growth. For the 
results of the random effect method, Table A6 shows the oil price changes have a significant positive effect whereas the volatility of oil price has an insignificant positive effect. Further, there is evidence that the effect of oil price changes on economic growth is asymmetric, the population growth has a negative significant effect and the capital formation has a positive significant effect. However, the exchange rate deviation does not have a significant effect on output growth.

Table A6 also provides the estimations of the dynamic GMM approach. As it is mentioned previously, the GMM approach produces consistent estimators with the dynamic form after passing the test of the validity of the included instruments. The J-statistic test confirms the validity of the model with the included instruments. The null hypothesis of the validity of the instruments could not be rejected. Table A6 indicates that the oil price changes have a significant and positive effect on the output growth whereas volatility of the oil price has an insignificant positive effect. Furthermore, the dummy variable for the asymmetric effect of the impact of oil price changes on economic growth and capital formation is significant. However, the exchange rate deviation does not have any significant effect on the growth of output. These results are supportive of all different static models. In summary, all linear models demonstrate robust results that the changes in the oil price have a significant and positive effect on the economic growth of the MENA countries and this effect is asymmetric.

Table A7 shows that the relationship between economic growth and oil price fluctuations is unlike for the analyzed quantiles. The effects of both oil price change and its uncertainty on economic growth are more significant in the upper quantiles relative to the lower quantiles. Regarding the effect of oil price changes, it can be observed that over the quantiles from 0.1 to 0.3 , this effect is insignificant or only significant with $10 \%$ whereas over the quantiles from 0.3 to 0.9 it is significant with probabilities $1 \%$ or $5 \%$. The effect of oil price volatility is only significant with upper quantiles starting from quantile 0.7. Furthermore, the effect of the asymmetric dummy variable for oil price changes is significant overall quantiles. This result brings more evidence about the importance of the asymmetric effect of oil price changes on the growth of the real product of the selected countries, as positive changes have different effects from those of the negative ones. These results confirm that the Q.R. gives more detailed results in comparison to other used linear models. Table A8 depicts the results of the symmetric quantiles test; it shows that the null hypothesis which implies estimated parameters are symmetric across different quantiles is rejected with a significant $1 \%$. Then, it might be claimed that the quantile regression approach is more appropriate for analyzing the underlying relationship.

Table A9 depicts the results of the previous five models after augmenting the institution quality index. It can be observed that the coefficient of institutional quality is significant and positive, which implies the institutional quality is crucial in enhancing GDP growth in MENA countries. Regarding the oil price fluctuation, its impact on GDP growth significant but it becomes smaller. In addition, for all models, the uncertainty of the oil price is insignificant with a negative sign, which reflects the importance of having reliable institutions to help in absorbing the likelihood of the oil price changes and its uncertainty.

\subsection{Robust analysis}

To check for more exploration about the impact of change in oil price and its volatility on each of oil-export countries and oil-import countries, a separate regression has been conducted for each group. Table A10 shows that both change in oil price and oil price volatility has an opposite effect on oil-export and oil-import countries. For oil-export countries, we can find that changes in oil prices have a positive significant effect on economic growth where the volatility of oil price has a negative but insignificant effect. However, for oil import countries, changes in 
oil prices have a significant negative effect where the volatility of oil prices has a positive significant effect. Furthermore, the dummy of asymmetric change in oil price has a positive effect on where population growth has a negative effect on both groups.

Furthermore, to check for more exploration to what extent the GDP growth is affected by oil price volatility, another step is to examine the robustness of the previous results for different measures of oil price volatility. Thus, a common technique for generating volatility for oil prices is applied (Mohaddes and Pesaran, 2014). According to this approach, the formula of the realized volatility for oil price can be written as follow:

$$
\operatorname{VCOP}_{t}^{0}=\sqrt{\frac{12}{=1}\left(D_{t, \omega}^{0}--D_{t, \omega}^{0}\right)^{2^{\omega=1}}}
$$

Where $D_{t, \omega}^{0}=C O P_{t},-D_{t, \omega}^{0}=\frac{1}{12} \sum_{\tau=1}^{12} D_{t, \omega}^{0}$ and $D_{t, \omega}^{0}$ express the oil price level in the year and within the month $\omega$.

Figure A7 displays the plot of the generated volatility by the more convenient standard approach along with the volatility generated with the GARCH approach. Table A11 shows the correlation matrix between the two volatilities. Where it can be observed that they are positively and strongly correlated. Table A12 depicts the results of the OLS method and the quantile approach using the more convenient standard deviation approach for the oil price volatility and it can be observed that results did not significantly change.

Moreover, to check in the extent of the results robustness for outliers in GDP growth rates, the extreme values were removed and the model was re-estimated, there is no considerable change in the results as outlined in Table A12. Furthermore, the effect on the volatility of the GDP growth is explored rather than on the GDP growth is attributed to the level of oil-price where this impact is negative. In addition, the effect of the oil price volatility on the GDP growth is insignificant.

\section{Conclusion}

The current study explores the effect of fluctuations in oil price, the volatility of oil price, the asymmetry in the impact of crude oil price on the real product of the MENA countries over a long period. The study uses four different linear models; three models are static (pooled OLS, fixed effect model and random effect model) and the fourth (GMM system) is dynamic. The system GMM overcomes the problem of endogeneity that resulted from adding the lagged of the dependent variable as a regressor inside the model. Furthermore, the paper uses the Q.R. approach to get a whole image of the distribution of the underlying relationship.

All used linear models (the static models and the dynamic model) provided robust results as the oil price changes have a significant positive effect whereas the volatility of oil price has an insignificant positive effect on the growth of real products. Further, all the used linear models support the asymmetric effect of changes in oil prices on economic growth. Furthermore, Q.R. gives more detailed results about the effect of the included variables on economic growth. Q.R. approach reveals that the effect of oil price and uncertainty of oil price on economic growth is more significant in the upper quantiles relative to the lower quantiles. In addition, the institutional efficiency has a significant positive effect on economic growth. Nevertheless, incorporating the institutional factor has caused a double effect; the crude oil price fluctuations have a smaller impact and the insignificance of the oil price volatility factor in all models. Furthermore, when a separate regression has been conducted for each MENA oil-export countries and MENA oil-import countries, changes in oil price and oil price volatility has an opposite effect on each group. For oil-export countries changes in oil prices have a significant positive impact but the volatility has a negative 
effect whereas for oil-import countries changes in oil prices have a significant negative effect, but volatility has a positive significant effect.

The recommendations of the study based on the results are: policymakers should be cautious against changes in oil price and building good institutions helps in absorbing the effect of oil price fluctuations. Further, as all models give significant, robust results about the effect of oil prices and volatility of oil prices, future studies should focus on determining the threshold level for this relationship by using one of the Panel Threshold models like Hansen (1999) or the modern threshold approach for Kremer et al. (2013). Moreover, the time-varying effect of oil price shocks on macroeconomic aggregates might be a good avenue for future research.

\section{References}

Akinlo, T. and Tolulope Apanisile, O. (2010), "The impact of volatility of oil price on the economic growth in sub-Saharan Africa", British Journal of Economics, Management and Trade, Vol. 5 No. 3, pp. 338-349, available at: https://doi.org/10.9734/BJEMT/2015/12921

Akinsola, O. and Nicholas, M. (2020), "Asymmetric effect of oil price on economic growth: panel analysis of low-income oil-importing countries", Energy Reports, Vol. 6, pp. 1057-1066, doi: 10.1016/j.egyr.2020.04.023.

Akpan, E.O. (2009), "Oil price shocks and nigeria's macroeconomy", Annual Conference of Centre for the Study of African Economies (CSAE): Economic Development in Africa, Oxford.

Anashasy, E.A., Bradly, D.B. and Joutz, F. (2005), "Evidence on the role of oil prices in Venezuela's economic performance:1950-2001”, Working Paper, George Washington University, available at: www.iaee.org/documents/denver/el-anshasy.pdf

Arouri, M.E.H. and Nguyen, D.K. (2010), "Oil prices, stock markets, and portfolio investment: evidence from sector analysis in Europe over the last decade”, Energy Policy, Vol. 38, pp. 4528-4539, doi: 10.1016/j.enpol.2010.04.007.

Baur, D.G. (2013), “The structure and degree of dependence: a quantile regression approach", Journal of Banking and Finance, Vol. 37 No. 3, pp. 786-798, doi: 10.1016/j.jbankfin.2012.10.015.

Berument, M.H., Ceylan, N.B. and Dogan, N. (2010), "The impact of oil price shocks on the economic growth of selected MENA countries", The Energy Journal, Vol. 31 No. 1, pp. 149-176, doi: 10.5547/ISSN0195-6574-EJ-Vol31-No1-7.

Bjornland, H.C. (2000), "The dynamic effects of aggregate demand, supply and oil price shocks - a comparative study", Manchester School, University of Manchester, Vol. 68 No. 5, pp. 578-607.

Bond, S., Hoeffler, A. and Temple, J. (2001), "GMM estimation of empirical growth models", Economics Papers 2001-W21, Economics Group, Nuffield College, University of Oxford.

Bouzid, A. (2012), "The relationship of oil prices and economic growth in Tunisia: a vector error correction model analysis", The Romanian Economic Journal Year, Vol. 15 No. 43.

Brini, R., Jemmali, H. and Farroukh, A. (2016), "Macroeconomic impacts of oil price shocks on inflation and real exchange rates: evidence from MENA economies", Topics in Middle Eastern and African Economies, Vol. 18 No. 2, pp. 170-185.

Cashin, P., Mohaddes, K. and Raissi, M. (2016), "The global impact of the systemic economies and MENA business cycles", in Elbadawi, I.A. and Selim, H. (Eds), Understanding and Avoiding the Oil Curse in Resource-Rich Arab Economies, Cambridge University Press, Cambridge, pp. 16-43.

Cavalcanti, T.V.D.V., Mohaddes, K. and Raissi, M. (2015), "Commodity price volatility and the sources of growth", Journal of Applied Econometrics, Vol. 30 No. 6, pp. 857-873.

Chuang, C.C., Kuan, C.M. and Lin, H.Y. (2009), "Causality in quantiles and dynamic stock returnvolume relations", Journal of Banking and Finance, Vol. 33 No. 7, pp. 1351-1360, doi: 10.1016/j. jbankfin.2009.02.013. 
Dabachi, U.M., Mahmood, S., Ahmad, A.U., Muhammad, A.A. and Kabiru, K. (2020), "Energy consumption, energy price, energy intensity environmental degradation, and economic growth nexus in african OPEC countries: evidence from simultaneous equations models", Journal of Environmental Treatment Techniques, Vol. 8 No. 1, pp. 403-409.

Das, D., Kumar, S.B., Tiwari, A.K., Muhammad, S. and Hasim, H.M. (2018), "On the relationship of gold, crude oil, stocks with financial stress: a causality-in-quantiles approach”, Finance Research Letters, Vol. 27, pp. 169-174.

Dehn, J. (2001), “The effects on growth of commodity price uncertainty and shocks”, Policy Research Working Paper 2455 World Bank, Development Research Group.

El-Anshasy, A., Mohaddes, K. and Nugent, J.B. (2017), "Oil, volatility and institutions: cross-country evidence from major oil producers", Globalization and Monetary Policy Institute Working Paper No. 310, available at: https://ssrn.com/abstract $=2962915$ or doi: $10.24149 / \mathrm{gwp} 310$

Elseoud, A. and Kreishan, F.M. (2020), "Energy-GDP nexus for oil-exporting country: the case of Bahrain”, International Journal of Energy Economics and Policy, Vol. 10 No. 6, pp. 80-86.

Farzanegan, M.R. and Markwardt, G. (2009), "The effects of oil price shocks on the Iranian economy", Energy Economics, Vol. 31 No. 1, pp. 134-151.

Filis, G., Degiannakis, S. and Floros, C. (2011), "Dynamic correlation between the stock market and oil prices: the case of oil-importing and oil-exporting countries", International Review of Financial Analysis, Vol. 20 No. 3, pp. 152-164, doi: 10.1016/j.irfa.2011.02.014.

Foudeh, M. (2017), "The long run effects of oil prices on economic growth: the case of Saudi Arabia", International Journal of Energy Economics and Policy, Vol. 7 No. 6, pp. 171-192.

Gbatu, A.P., Wang, Z., Wesseh, P.K., Jr and Tutdel, I.Y.R. (2017), "The impacts of oil price shocks on small oil-importing economies: time series evidence for Liberia”, Energy, Vol. 139, pp. 975-990.

Gershon, O., Ezenwa, N. and Osabohien, R. (2019), "Implications of oil price shocks on net oil-importing African countries", Heliyon, Vol. 5 No. 8, p. e02208, available at: https://doi.org/10.1016/j. heliyon.2019.e02208

Ghalayini, L. (2011), “The interaction between oil price and economic growth”, Review of Middle East Economics and Finance, Vol. 13 No. 13, pp. 127-141.

Hamilton, J.D. (1983), “Oil and the macroeconomy since World War II”, Journal of Political Economy, Vol. 91, pp. 228-248.

Hamilton, J. (2003), "This is what happened to the oil price-macroeconomy relationship", Journal of Monetary Economics, Vol. 38 No. 2, pp. 215-220, doi: 10.1016/S0304-3932(96)01282-2.

Hamilton, J.D. (2008), "Oil and the macroeconomy", in Durlauf, S. and Blume, L. (Eds), The New Palgrave Dictionary of Economics, 2nd ed., Palgrave MacMillan Ltd.

Hansen, B.E. (1999), "Threshold effects in non-dynamic panels: estimation, testing, and inference", Journal of Econometrics, Vol. 93 No. 2, pp. 345-368, doi: 10.1016/S0304-4076(99)00025-1.

Hauk, W. and Wacziarg, R. (2009), “A Monte Carlo study of growth regressions”, Journal of Economic Growth, Vol. 14 No. 2, pp. 103-147.

Hausmann, R. and Rigobon, R. (2003), “An alternative interpretation of the 'resource curse': theory and policy implications", National Bureau of Economic Research Working Paper No. 9424 Issued in January 2003, available at: www.nber.org/papers/w9424

Jarrett, U., Mohaddes, K. and Mohtadi, H. (2018), "Oil price volatility, financial institutions and economic growth", Cambridge Working Papers in Economics 1851, Faculty of Economics, University of Cambridge, available at: https://doi.org/10.1016/j.enpol.2018.10.068

Jahangir, R. and Dural, B. (2018), "Crude oil, natural gas, and economic growth: impact and causality analysis in Caspian Sea region”, International Journal of Management and Economics, Vol. 54 No. 3, pp. 169-184, doi: 10.2478/ijme-2018-0019. 
Jiménez-Rodríguez, R. and Sánchez, M. (2004), "Oil price shocks and real GDP growth: empirical evidence for some OECD countries", Applied Economics, Vol. 37 No. 2, pp. 201-228, doi: 10.1080/ 0003684042000281561.

Kilian, L. and Vigfusson, R.J. (2011), "Nonlinearities in the oil price-output relationship", Macroeconomic Dynamics, Vol. 15 No. S3, pp. 337-363.

Kilian, L. and Vigfusson, R. (2013), "Do oil prices help forecast U.S. real GDP? The role of nonlinearities and asymmetries", Journal of Business \& Economic Statistics, Vol. 31 No. 1, pp. 78-93.

Koenker, R. (2004), "Quantile regression for longitudinal data”, Journal of Multivariate Analysis, Vol. 91 No. 1, pp. 74-89.

Koenker, R. and Bassett, G. Jr. (1978), “Regression quantiles”, Econometrica, Vol. 46 No. 1, pp. 33-50, doi: 10.2307/1913643.

Kousar, R., Makhdum, M.S.A., Naqvi, S.A.A., Asif, M. and Sadaf, T. (2019), "A time series analysis of energy consumption, energy prices and economic growth in Pakistan", European Online Journal of Natural and Social Sciences, Vol. 8 No. 4, pp. 687-707.

Kremer, S., Bick, A. and Nautz, D. (2013), "Inflation and growth: new evidence from a dynamic panel threshold analysis", Empirical Economics, Vol. 44 No. 2, pp. 861-878, available at: https://doi.org/ 10.1007/s00181-012-0553-9

Lin, H.Y. (2013), "Dynamic stock return-volume relation: evidence from emerging Asian markets", Bulletin of Economic Research, Vol. 65 No. 2, pp. 178-193, doi: 10.1111/j.1467-8586.2011.00428.x.

Maalel, N.F. and Mahmood, H. (2018), "Oil-abundance and macroeconomic performance in the GCC countries”, International Journal of Energy Economics and Policy, Vol. 8 No. 2, pp. 182-187.

Mahmood, H. and Zamil, A.M.A. (2019), "Oil price and slumps effects on personal consumption in Saudi Arabia”, International Journal of Energy Economics and Policy, Vol. 9 No. 4, pp. 12-15.

Mankiw, G., Romer, D. and Weil, D. (1992), "A contribution to the empirics of economic growth", The Quarterly Journal of Economics, Vol. 107 No. 2, pp. 407-437.

Mehrara, M. and Oskoui, K. (2007), "The source of macroeconomic fluctuations in oil exporting countries: A comparative study”, Economic Modelling, Vol. 24 No. 3, pp. 365-379.

Mensi, W., Hammoudeh, S., Reboredo, J.C. and Nguyen, D. (2014), "Do global factors impact BRICS stock markets? A quantile regression approach”, Emerging Markets Review, Vol. 19 No. 2, pp. 1-17, doi: 10.1016/j.ememar.2014.04.002.

Mgbame, C.O., Donwa, P.A. and Onyeokweni, O.V. (2015), "Impact of oil price volatility on economic growth: conceptual perspective", International Journal of Multidisciplinary Research and Development, Vol. 2 No. 9, pp. 80-85.

Miguel, C., Manzano, B. and Martin-Moreno, J. (2003), "Oil price shocks and aggregate fluctuations", The Energy Journal, Vol. 24 No. 2, pp. 47-61.

Mohaddes, K. and Pesaran, M.H. (2014), "One hundred years of oil income and the Iranian economy: a curse or a blessing?", in Alizadeh, P. and Hakimian, H. (Eds), Iran and the Global Economy: Petro Populism, Islam and Economic Sanctions, Routledge, London.

Murshed, M. and Tanha, M.M. (2020), "Oil price shocks and renewable energy transition: Empirical evidence from net oil-importing South Asian economies”, Energy, Ecology and Environment, Vol. 338.

Newey, W.K. and Powell, J.L. (1987), “Asymmetric least squares estimation”, Econometrica, Vol. 55 No. 4, pp. 819-847, doi: 10.2307/1911031.

Okonju, C. (2009), "Oil price fluctuations and its effects on growth", Journal of Historical Economics, Vol. 2 No. 5, pp. 15-18.

Papapetrou, E. (2001), "Oil prices shocks, stock market, economic activity and employment in Greece", Energy Economics, Vol. 23 No. 5, pp. 511-532.

Raheem, I.D. (2017), "Asymmetry and break effects of oil price-macroeconomic fundamentals dynamics: the trade effect channel”, The Journal of Economic Asymmetries, Vol. 16, pp. 12-25. 
Rahman, M.H. and Majumder, S.C. (2020), "Nexus between energy consumptions and $\mathrm{CO}_{2}$ emissions in selected industrialized countries", International Journal of Entrepreneurial Research, Vol. 3 No. 1, pp. 13-19.

Saban, N., Gormus, A. and Ugur, S. (2019), "Oil prices and monetary policy in emerging markets: structural shifts in causal linkages", Emerging Markets Finance and Trade, Vol. 55 No. 1, pp. 105-117.

Saddiqui, S.A., Jawad, M., Naz, M. and Niazi, G.S.K. (2018), "Exchange rate, fiscal policy and international oil prices impact on oil prices in Pakistan: a volatile and granger causality analysis", Review of Innovation and Competitiveness, Vol. 4 No. 1, pp. 27-46.

Selim, H. and Zaki, C. (2014), "The institutional curse of natural resources in the Arab world", Working Papers 890, Economic Research Forum, revised Dec 2014.

Sill, K. (2007), "The macroeconomics of oil shocks", Bus. Rev, Vol. 1 No. 1, pp. 21-31.

Solow, R. (1956), "A contribution to the theory of economic growth", The Quarterly Journal of Economics, Vol. 70 No. 1, pp. 65-94.

Van Eyden, R., Difeto, M., Gupta, R. and Wohar, M.E. (2019), "Oil price volatility and economic growth: evidence from advanced economies using more than a century's data”, Applied Energy, Vol. 233, pp. 612-621.

Vespignani, J., Raghavan, M. and Kumar, M. (2019), “Oil curse, economic growth and trade openness”, Globalization Institute Working Paper 370, available at: https://doi.org/10.24149/gwp370

Vohra, R. (2017), "The impact of oil prices on GCC economies", International Journal of Business and Social Science, Vol. 8 No. 2.

Ziliak, J.P. (1997), "Efficient estimation with panel data when instruments are predetermined: an empirical comparison of moment-condition estimators", Journal of Business and Economic Statistics, Vol. 15 No. 4, pp. 419-431, doi: 10.1080/07350015.1997.10524720.

\section{Further reading}

Alquist, R., Kilian, L. and Vigfusson, R.J. (2013), "Forecasting the price of oil", in Elliott, G. and Timmermann, A. (Eds), Handbook of Economic Forecasting, Edition 1, Elsevier, Vol. 2, pp. 427-507.

Chang, Y. and Wong, J.F. (2003), "Oil price fluctuations and Singapore economy”, Energy Policy, Vol. 31 No. 11, pp. 1151-1165, doi: 10.1016/S0301-4215(02)00212-4, available at: https://doi.org/10.1016/ S0301-4215(02)00212-4

Cheng, H., Gutierrez, M., Maghajan, A., Sachumurove, Y. and Shakrokhi, M. (2007), "A future global economy to be built by BRICs", Global Finance Journal, Vol. 18 No. 2, pp. 143-156.

Das, D., Bhatia, V., Pillai, J. and Tiwari, A. (2018), "The relationship between oil prices and US economy revisited", Energy Sources, Part B: Economics, Planning, and Policy, Vol. 13, doi: 10.1080/ 15567249.2017.1403497.

Devlin, J. and Lewin, M. (2004), "Managing oil booms and busts in developing countries", Draft Chapter for: Managing Volatility and Crises, A Practitioner's Guide, doi: 10.1017/CBO9780511510755.008.

Doğrul, H.G. and Soytas, U. (2010), "The relationship between oil prices, interest rate, and unemployment: evidence from an emerging market", Energy Economics, Vol. 32 No. 6, pp. 1523-1528, doi: 10.1016/j.eneco.2010.09.005.

Hatemi-J, A. (2012), "Asymmetric causality tests with an application”, Empirical Economics, Vol. 43 No. 1, pp. 447-456, doi: 10.1007/s00181-011-0484-x.

Holtz-Eakin, D., Newey, W. and Rosen, H.S. (1988), "Estimating vector autoregressions with panel data", Econometrica, Vol. 56 No. 6, pp. 1371-1395, doi: 10.2307/1913103.

Im, K.S., Pesaran, M.H. and Shin, Y. (2003), "Testing for unit roots in heterogeneous panels", Journal of Econometrics, Vol. 115 No. 1, pp. 53-74, doi: 10.1016/S0304-407. 
Kao, C. (1999), "Spurious regression and residual-based tests for cointegration in panel data", Journal of Econometrics, Vol. 90 No. 1, pp. 1-44, doi: 10.1016/S0304-4076(98)00023.

Lee, K., Lee, B. and Ratti, R. (2001), "Monetary policy, oil price shocks, and the Japanese economy", Japan and the World Economy, Vol. 13 No. 3, pp. 321-349.

Levin, A., Lin, C.F. and Chu, C.S.J. (2002), "Unit root tests in panel data: asymptotic and finite sample properties", Journal of Econometrics, Vol. 108 No. 1, pp. 1-24, available at: https://doi.org/ 10.1016/S0304-4076(01)00098-7

Odhiambo, N.M. (2020), "Oil price and economic growth of oil-importing countries: a review of international literature, Applied Econometrics and International Development, Vol. 20.

Vespignani, J.M. and Raghavan, M.K. (2019), "Oil curse, economic growth and trade openness", Globalization Institute Working Paper, Vol. 2019, available at: https://doi.org/10.24149/ gwp370.

Widarjono, A. and Susantun, I. (2020), "Oil and food prices for a net oil importing-country: how are related in Indonesia?", International Journal of Energy Economics and Policy, Vol. 10 No. 5, pp. 255-263. 
Figure A1.

Development of oil prices over the study period

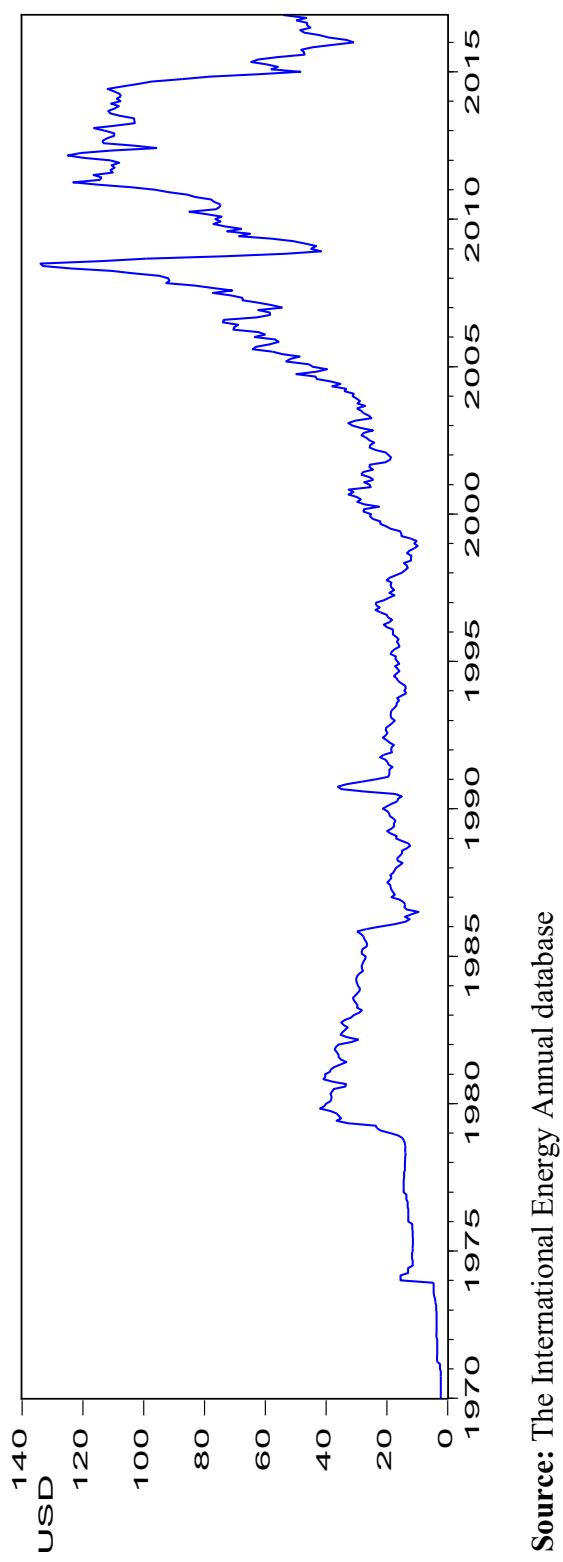



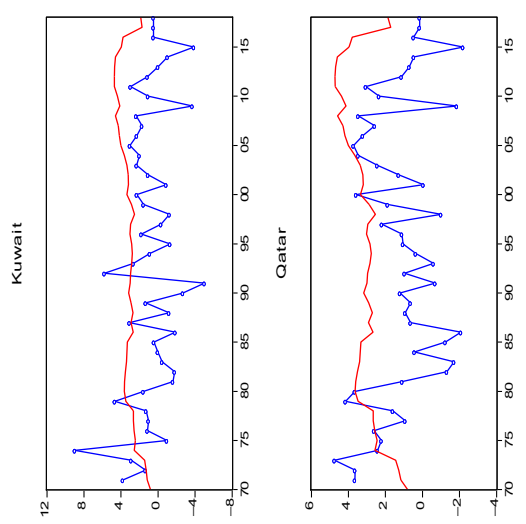

Oil price fluctuations and economic growth
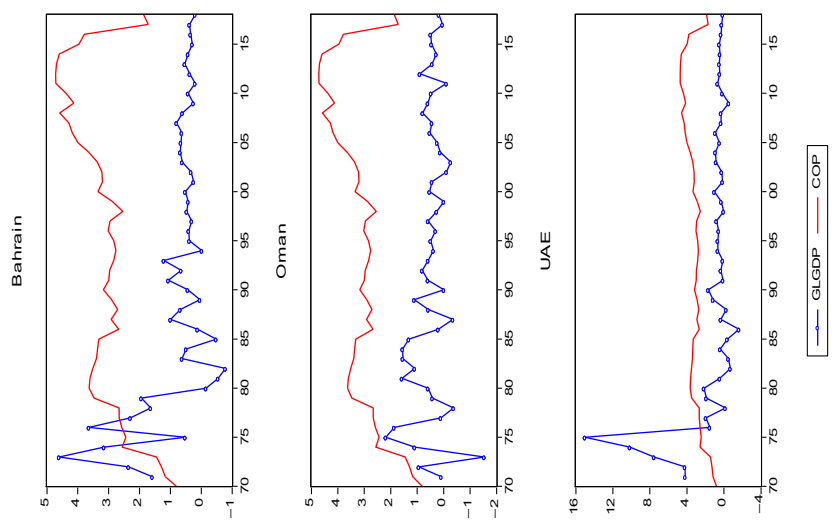

Figure A2.
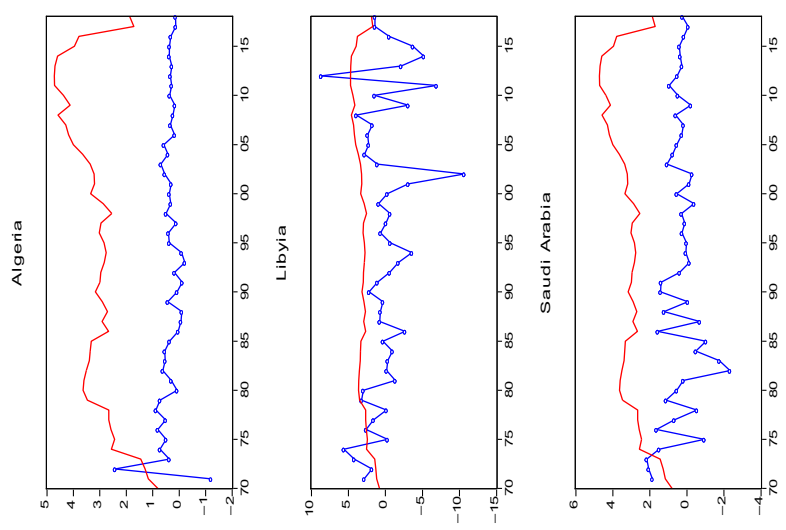

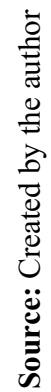

The development of crude oil price and GDP growth for MENA oil-export countries 


\section{REPS}


Figure A3.

The development of crude oil price volatility and GDP for MENA oil-export countries
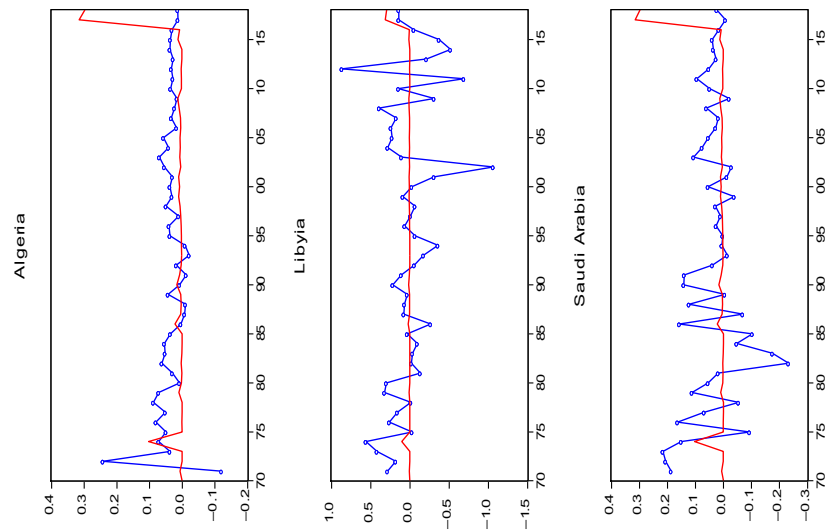

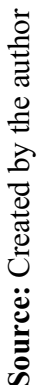



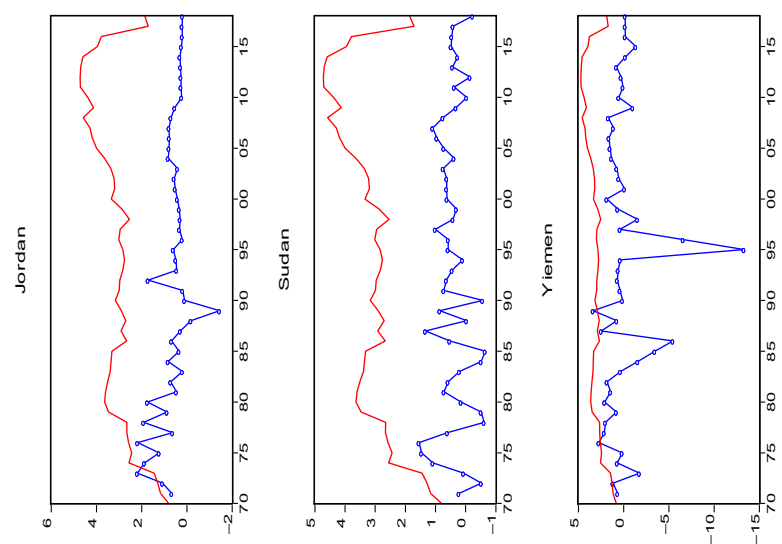

\section{Oil price fluctuations and economic growth}
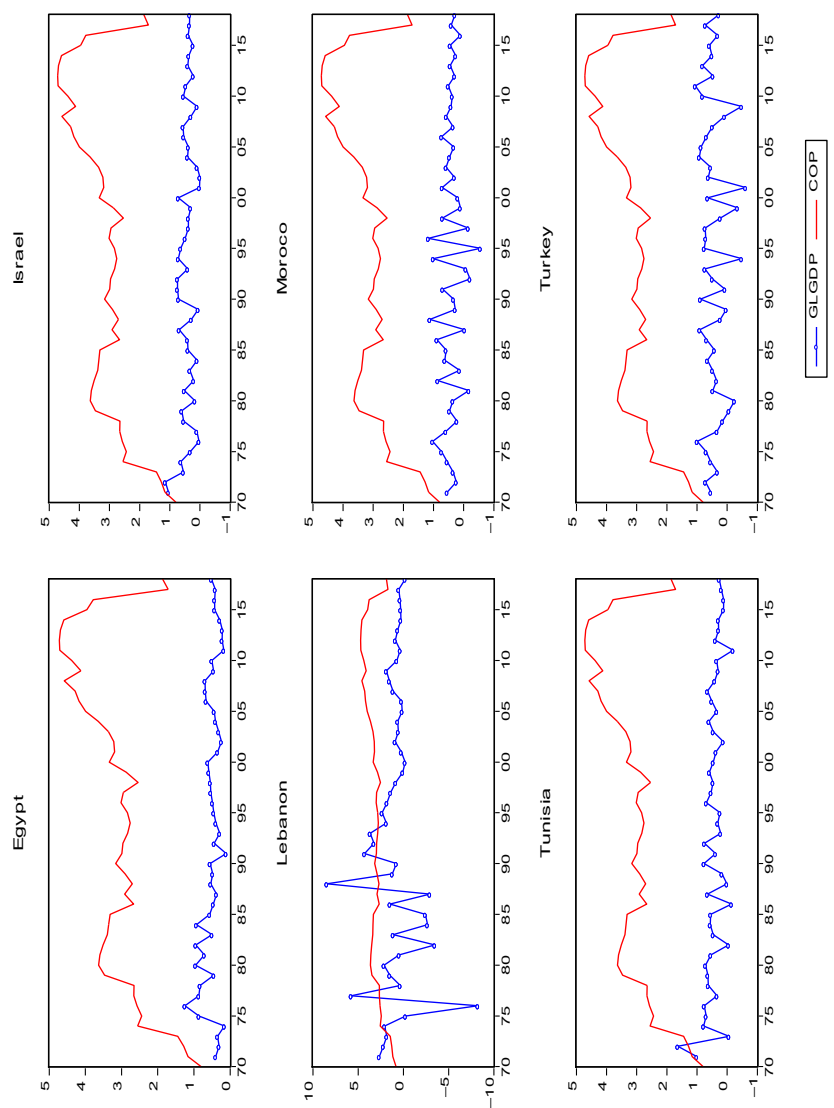

Figure A4.

The development of crude oil price and GDP for MENA oilimport countries 


\section{REPS}

Figure A5.

The development of crude oil price volatility and GDP for MENA oil-import countries
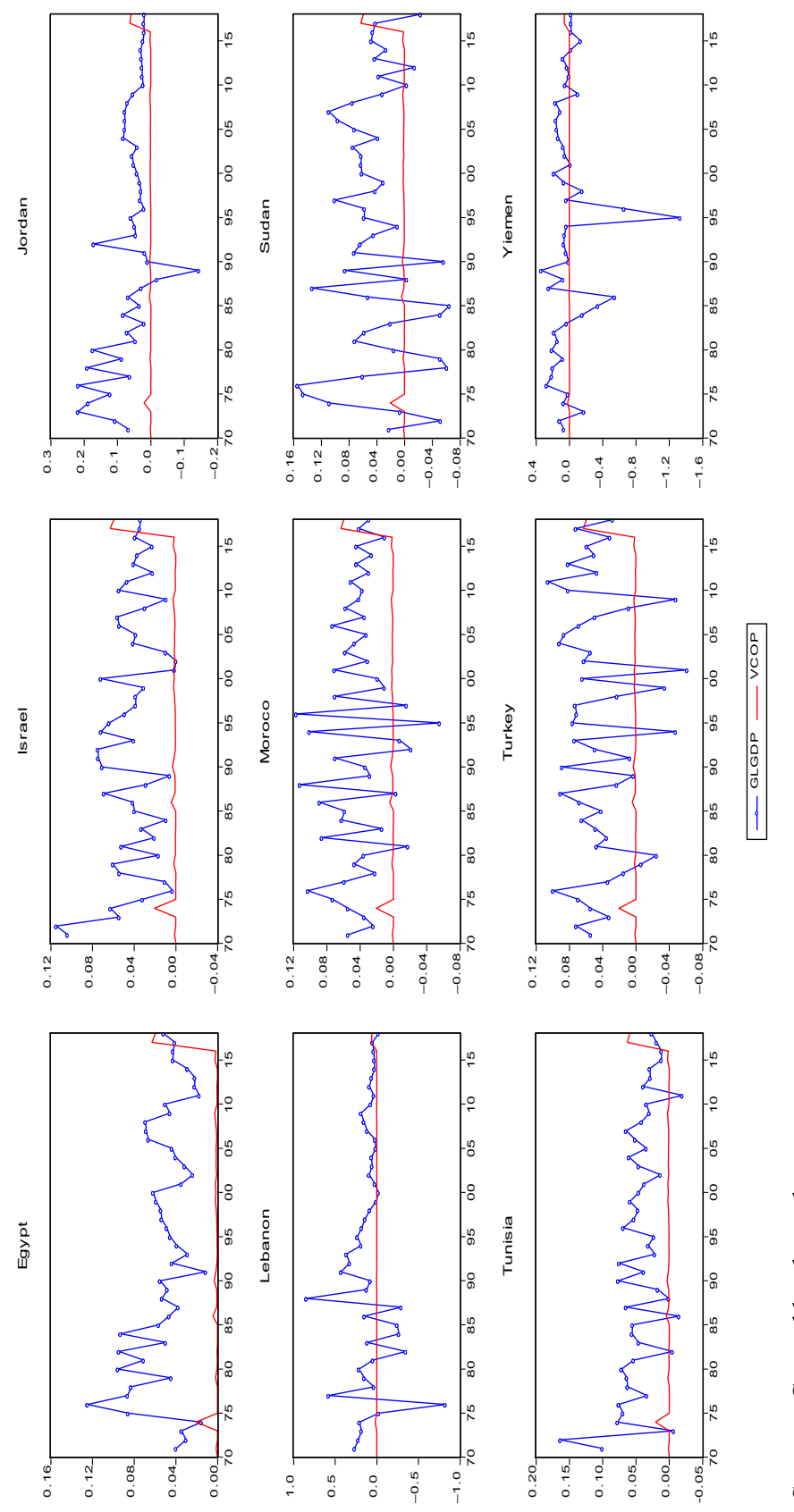

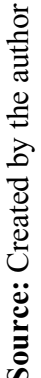




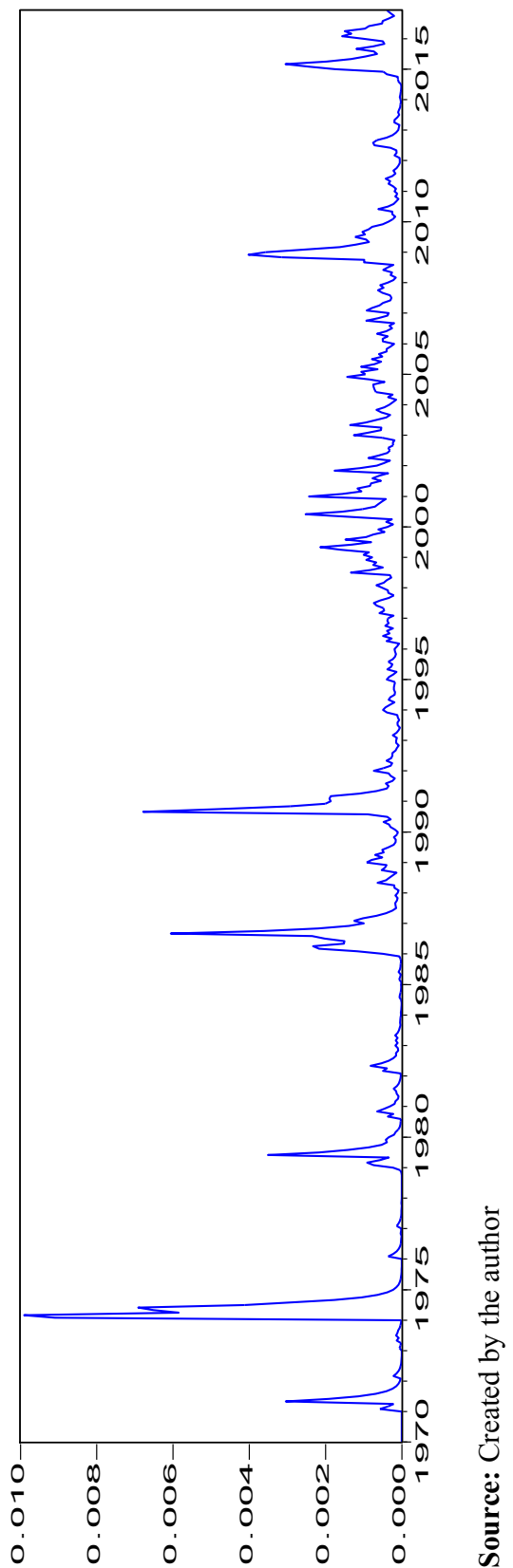

Oil price fluctuations and economic growth

Figure A6. The volatility of oil price over the period of study 


\section{REPS}

Figure A7.

Different kinds of oil price volatility

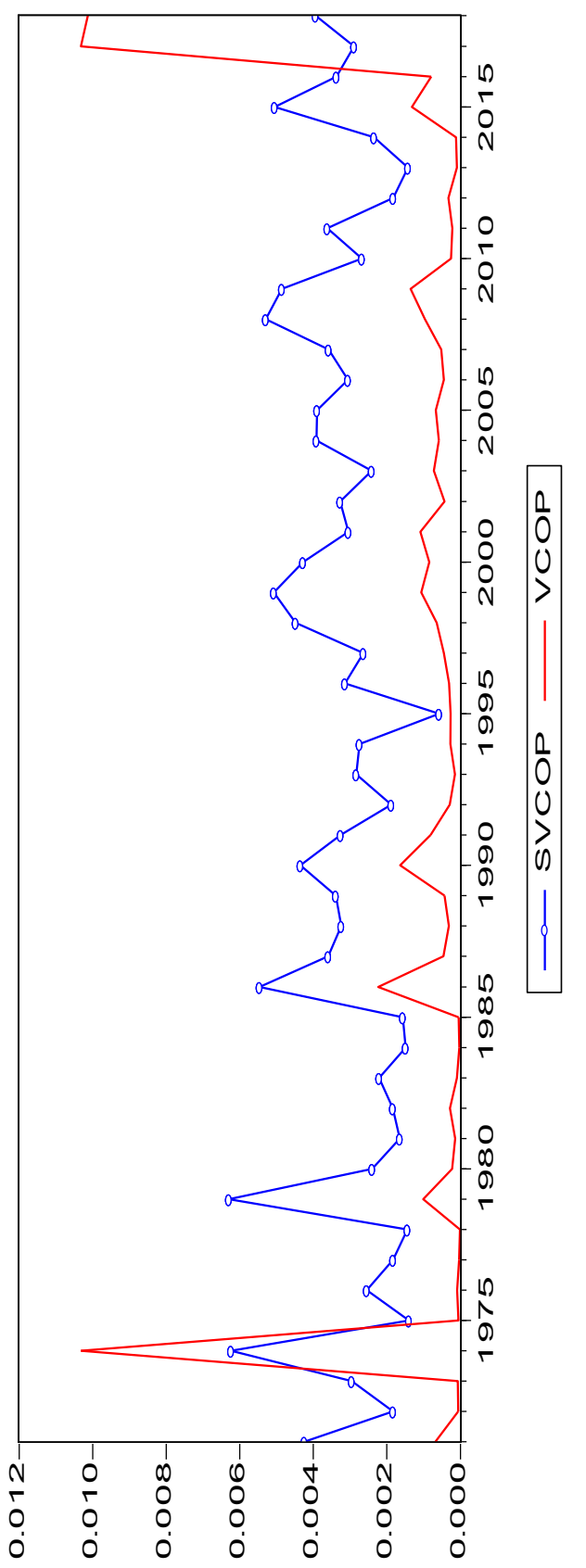

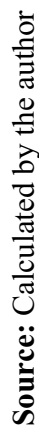




\begin{tabular}{lccccccccc}
\hline Measure & Y & COP & VCOP & ERD & ALD & GFC & PG & SSE & INS \\
\hline Mean & 0.055 & 0.064 & 0.0007 & -0.0001 & 12.930 & 23.242 & 3.35 & 65.92 & 4.970 \\
Median & 0.046 & 0.049 & 0.0003 & -0.0030 & 14.125 & 23.128 & 2.58 & 70.26 & 5.200 \\
Maxi & 0.897 & 1.11 & 0.0103 & 1.1003 & 17.0650 & 26.590 & 17.63 & 98.46 & 6.610 \\
Min & -1.331 & -0.65 & 0.00006 & -0.7378 & 6.90775 & 19.406 & -3.10 & 0.000 & 0.710 \\
Std. & & & & & & & & & \\
dev. & 0.155 & 0.31 & 0.00150 & 0.1297 & 2.9712 & 1.366 & 2.62 & 27.29 & 1.086 \\
& 2,035 & 206 & $3,9362.4$ & $8,977.66$ & 61.678 & 9.12 & $3,630.0$ & 30.58 & 120 \\
Jarque & $(0.00)$ & $(0.00)$ & $(0.00)$ & $(0.00)$ & $(0.00)$ & $(0.01)$ & $(0.000)$ & $(0.00)$ & $(0.00)$
\end{tabular}

Oil price fluctuations and economic growth

Source: Created by the author

Table A1. Descriptive statistics

\begin{tabular}{lrrrrrrrrr}
\hline Variable & Y & COP & VCOP & EPG & ERD & GFC & PG & SSE & INS \\
\hline$Y$ & 1.000 & 0.270 & -0.376 & -0.207 & -0.078 & -0.028 & 0.081 & 0.151 & 0.241 \\
COP & 0.270 & 1.000 & -0.214 & -0.268 & -0.075 & -0.461 & 0.551 & 0.286 & 0.497 \\
VCOP & -0.376 & -0.214 & 1.000 & 0.051 & 0.029 & -0.010 & -0.075 & -0.051 & -0.119 \\
EPG & -0.207 & -0.268 & 0.051 & 1.000 & 0.042 & -0.315 & -0.023 & -0.512 & -0.568 \\
ERD & -0.078 & -0.075 & 0.029 & 0.042 & 1.000 & -0.136 & 0.013 & -0.125 & 0.079 \\
GFC & -0.028 & -0.461 & -0.010 & -0.315 & -0.136 & 1.000 & -0.566 & 0.324 & -0.326 \\
$P G$ & 0.081 & 0.551 & -0.075 & -0.023 & 0.013 & -0.566 & 1.000 & 0.310 & 0.493 \\
SSE & 0.151 & 0.286 & -0.051 & -0.512 & -0.125 & 0.324 & 0.310 & 1.000 & 0.360 \\
INS & 0.241 & 0.497 & -0.119 & -0.568 & 0.079 & -0.326 & 0.493 & 0.360 & 1.000
\end{tabular}

Source: Calculated by the author

Table A2.

Correlation matrix for MENA oil-export countries

\begin{tabular}{lrrrrrrrrr}
\hline Variable & GLGDP & \multicolumn{1}{c}{ COP } & VCOP & EPG & ERD & GFC & PG & SSE & INS \\
\hline GLGDP & 1.000 & -0.022 & 0.038 & 0.192 & -0.023 & -0.003 & -0.143 & 0.058 & 0.172 \\
COP & -0.022 & 1.000 & -0.144 & 0.102 & -0.034 & 0.098 & -0.175 & 0.042 & 0.275 \\
VCOP & 0.038 & -0.144 & 1.000 & 0.015 & 0.146 & 0.045 & 0.015 & 0.009 & -0.133 \\
EPG & 0.192 & 0.102 & 0.015 & 1.000 & -0.041 & 0.556 & -0.594 & -0.063 & -0.046 \\
ERD & -0.023 & -0.034 & 0.146 & -0.041 & 1.000 & 0.038 & 0.084 & -0.002 & -0.171 \\
GFC & -0.003 & 0.098 & 0.045 & 0.556 & 0.038 & 1.000 & -0.351 & 0.520 & -0.441 \\
$P G$ & -0.143 & -0.175 & 0.015 & -0.594 & 0.084 & -0.351 & 1.000 & 0.054 & 0.153 \\
SSE & 0.058 & 0.042 & 0.009 & -0.063 & -0.002 & 0.520 & 0.054 & 1.000 & -0.278 \\
INS & 0.172 & 0.275 & -0.133 & -0.046 & -0.171 & -0.441 & 0.153 & -0.278 & 1.000
\end{tabular}

Source: Calculated by the author

Table A3.

Correlation matrix for MENA oil-import countries 


\section{REPS}

\begin{tabular}{lcc}
\hline Variable & $\mathrm{ADF}$ & $\mathrm{PP}$ \\
\hline$C O P$ & $-13.80(0.0000)^{* * * *}$ & $-13.792(0.0000)^{* * * *}$ \\
$V C O P$ & $-4.564(0.0002)^{* * * *}$ & $-4.575(0.000)^{* * * *}$ \\
$Y$ & $217.306(0.000)^{* * *}$ & $365.723(0.000)^{* * * *}$ \\
$E R$ & $229.899(0.000)^{* * *}$ & $131.014(0.000)^{* *}$ \\
$A L D$ & $77.1695(0.000)^{* * *}$ & $99.048(0.000)^{* * *}$ \\
$E P G$ & $61.86(0.002)^{* * *}$ & $66.54(0.000)^{* * *}$ \\
$G F C$ & $12.583(0.05)^{*}$ & $57.62(0.000)^{* * * *}$ \\
$P G$ & $107.05(0.000)^{* * *}$ & $56.2(0.000)^{* * *}$ \\
$S S E$ & $12.27(0.05)^{*}$ & $42.29(0.04)^{* *}$ \\
$I N S$ & $87.09(0.000)^{* * *}$ & $46.44(0.047)^{* *}$
\end{tabular}

Table A4.

Notes: ***Means the coefficient is significant with 1,5 and $10 \%$; **indicate the coefficient is significant Unit root statistics with probability 5 and $10 \%$; *indicates significant with probability $10 \%$

Source: Calculated by the author

Table A5.

Volatility of oil prices generated from the GARCH model
Coefficient

Probability

Variable

1.179471

$-0.179295$

0.0000

$C O P(-1)$
COP $(-2)$

0.00488

0.169321

0.596515

2.967606

0.995065

0.995057

Rsquared

Durbin-Watson stat

1.974966
0.0000

0.2825

0.0000

0.0000

0.0000

Source: Calculated by the author 


\begin{tabular}{|c|c|c|c|c|}
\hline Variable & Pooled OLS method & Fixed effect method & Random effect method & GMM \\
\hline C & - & $0.165[0.77,0.441]$ & $0.047136[2.3,0.01]^{* *}$ & - \\
\hline$Y_{\text {it }-1}$ & - & - & - & $-0.4185\left[\begin{array}{lll}0.94 & 0.34\end{array}\right]$ \\
\hline$I L G D P_{i t}$ & $0.287[5.29,0.00]^{* * *}$ & & $0.3[2.86,0.00]^{* * *}$ & \\
\hline$C O P_{t}$ & $0.096[3.6,0.00]^{* * * *}$ & $0.082[3.3,0.00]^{* * *}$ & $0.095[3.9,0.00]^{* * *}$ & $0.19[2.16,0.03]^{* *}$ \\
\hline$V C O P_{t}$ & $2.88[0.51,0.6]$ & $0.44[0.83,0.4]$ & $2.785[0.47,0.63]$ & $2.8[0.81,0.41]$ \\
\hline$E R D_{i t}$ & $0.007[0.48,0.62]$ & $-0.00702[-0.1,0.8]$ & $-0.0086[-0.24,0.8]$ & $0.311[1.31,0.1]$ \\
\hline$A L D_{i t}$ & $-0.0138[-2.1,0.02]^{* * *}$ & $-0.015[-1.7,0.09]^{* * *}$ & $-0.01[-2.3,0.02]^{* *}$ & $-0.071[-3.8,0.00]^{* *}$ \\
\hline$G F C_{i t}$ & $0.0166[2.87,0.00]^{* * * *}$ & $0.0185[1.23,0.2]$ & $0.021[2,0.04]^{* *}$ & $0.12[2.6,0.00]^{* * * *}$ \\
\hline$P G_{i t}$ & $-0.016[-2.3,0.01]^{* *}$ & $-0.02[-2.73,0.00]^{* * * *}$ & $-0.019[-2.5,0.01]^{* *}$ & $-4.43[1.53,0.00]^{* * * *}$ \\
\hline$S S E_{i t}$ & $-0.0013[-2.7,0.00]^{* * * *}$ & $-0.003[-2.7,0.00]^{* * * *}$ & $-0.0013[-254,0.01]^{* *}$ & $-2.8[-2.8,0.00]^{* * * x}$ \\
\hline$E P G_{i t}$ & $-0.001[-1.8,0.07]^{*}$ & $0.0017[1.94,0.05]^{*}$ & $-0.0005[-0.74,0.45]$ & $0.0012[0.47,0.631]$ \\
\hline As_Dum & $0.034[2.4,0.01]^{* * *}$ & $0.029[2.065,0.03]^{* *}$ & $0.033\left[2.42,0.015^{* *}\right.$ & $0.176[2.45,0.01]^{* *}$ \\
\hline OED & $0.0414[2.49,0.01]^{* *}$ & & $0.0299[1.69,0.09]^{*}$ & $-0.008[-0.132,0.8]$ \\
\hline$F$-statistic & $9.75[0.00]^{* * *}$ & $5.56[0.00]^{* * *}$ & $7.832[0.00]^{* * *}$ & \\
\hline J-statistic & & & & $0.119[0.98]$ \\
\hline
\end{tabular}

Notes: Numbers between [] are t-static value and its probabilities; ${ }^{* * *}$ means the coefficient is significant with 1,5 and $10 \%$; ${ }^{* *}$ indicate the coefficient is significant with probability 5 and $10 \%$; indicates significant with probability $10 \%$

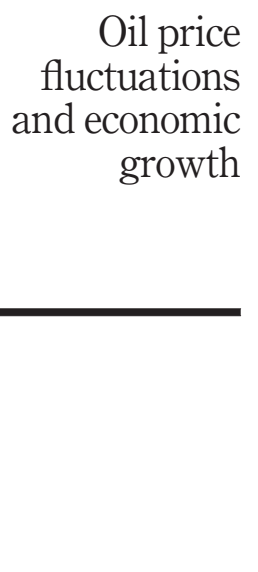

Table A6.

Estimates of linear models

\begin{tabular}{|c|c|c|c|c|c|c|c|}
\hline Variable & 0.1 & 0.2 & 0.3 & 0.4 & 0.5 & 0.7 & 0.9 \\
\hline ILGDP & $-0.3[0.00]^{* k * k}$ & $-0.04[0.4]$ & $0.0029[0.9]$ & $0.036[0.3]$ & $0.045[0.2]$ & $0.19[0.00]^{\text {**/k }}$ & $0.7[0.00]^{* * 2 * k}$ \\
\hline$C O P$ & $0.03[0.1]$ & $0.02[0.04]^{*}$ & $0.02[0.00]^{\text {*冰水 }}$ & $0.023[0.00]^{* * k_{k} \cdot k}$ & $0.027[0.00]^{\text {**akk }}$ & $0.02[0.01]^{\text {*e/k }}$ & $0.09[0.00]^{\text {*kek }}$ \\
\hline$V C O P$ & $0.1[0.7]$ & $0.13[0.5]$ & $0.3[0.19]$ & $0.29[0.33]$ & $0.35[0.2]$ & $0.9[0.04]^{* * *}$ & $4.8[0.00]^{* * * * k}$ \\
\hline$E R D$ & $-0.0003[0.9]$ & $-0.013[0.5]$ & $0.0084[0.6]$ & $-0.003[0.9]$ & $-0.001[0.9]$ & $-0.004[0.7]$ & $-0.03[0.8]$ \\
\hline$A L D$ & $-0.015[0.00]^{\text {3ek*k }}$ & $-0.007[0.002]^{\text {*2*k }}$ & $-0.007[0.00]^{\text {kek*k }}$ & $-0.005[0.01]^{* * k}$ & $-0.005[0.02]^{* * * k}$ & $-0.003[0.1]$ & $-0.004[0.57]$ \\
\hline$G F C$ & $0.01[01]^{* * k}$ & $0.008[0.00]^{* * *}$ & $0.008[0.00]^{\text {*w*⿰冫⿰亅⿱丿丶丶 }}$ & $0.007[0.00]^{* * * *}$ & $0.007[0.00]^{* * *}$ & $0.007[0.00]$ & $0.012[0.06]^{*}$ \\
\hline$P G$ & $-0.02[0.00]^{* * * * *}$ & $-0.005[0.1]$ & $-0.003[0.2]$ & $-0.002[0.4]$ & $-0.004[0.2]$ & $-0.008[0.00]^{* * * k}$ & $-0.029[0.00]^{* * * * * *}$ \\
\hline SSE & $-0.0006[0.00]^{* * * * *}$ & $-0.0004[0.05]^{*}$ & $-0.0004[0.00]^{* * \cdots * k}$ & $-0.00036[0.01]^{* * *}$ & $-0.0003[0.04]^{* * *}$ & $-0.0004[0.02]^{* * *}$ & $-0.0007[0.03]^{* * *}$ \\
\hline$E P G$ & $-0.0004[0]$. & $0.00011[0.7]$ & $0.00022[0.4]$ & $0.00021[0.4]$ & $0.0002[0.5]$ & $-0.0004[0.1]$ & $-0.003[0.00]^{* * * k}$ \\
\hline As-Dum & $0.02[2,0.00]^{* * \cdots * k}$ & $0.017[0.00]^{\text {*wak }}$ & $\left.0.015[0.005]^{* * * * *}\right]$ & $0.015[0.00]^{\text {*k*k*k }}$ & $0.02[0.00]^{* * * 2 * k}$ & $0.01[0.00]^{* * * *}$ & $0.02[0.00]^{* * \cdot k}$ \\
\hline$O E D$ & $-0.03[0.18]$ & $-0.017[0.2]$ & $-0.02[0.09]^{*}$ & $-0.005[0.6]$ & $-0.004[0.7]$ & $0.03[0.03]^{\text {***k }}$ & $6.8[0.00]^{* * * * k}$ \\
\hline
\end{tabular}

Notes: Numbers between are the probability of $t$-static; ${ }^{* * * *}$ means the coefficient is significant with 1,5 and $10 \%$; ${ }^{*}$ indicate the coefficient is significant with probability 5 and $10 \%$; * indicates significant with probability $10 \%$

Table A7.

Estimates of the quantile approach

\begin{tabular}{lcc}
\hline Test summary & Chi-square statistic & Prob \\
\hline Wald test & 16.9022 & $0.004^{* * * *}$
\end{tabular}

Notes: **Means the coefficient is significant with 1,5 and $10 \% ; *$ indicate the coefficient is significant with probability 5 and $10 \%$; *indicates significant with probability $10 \%$

Table A8.

Symmetric quantiles test 


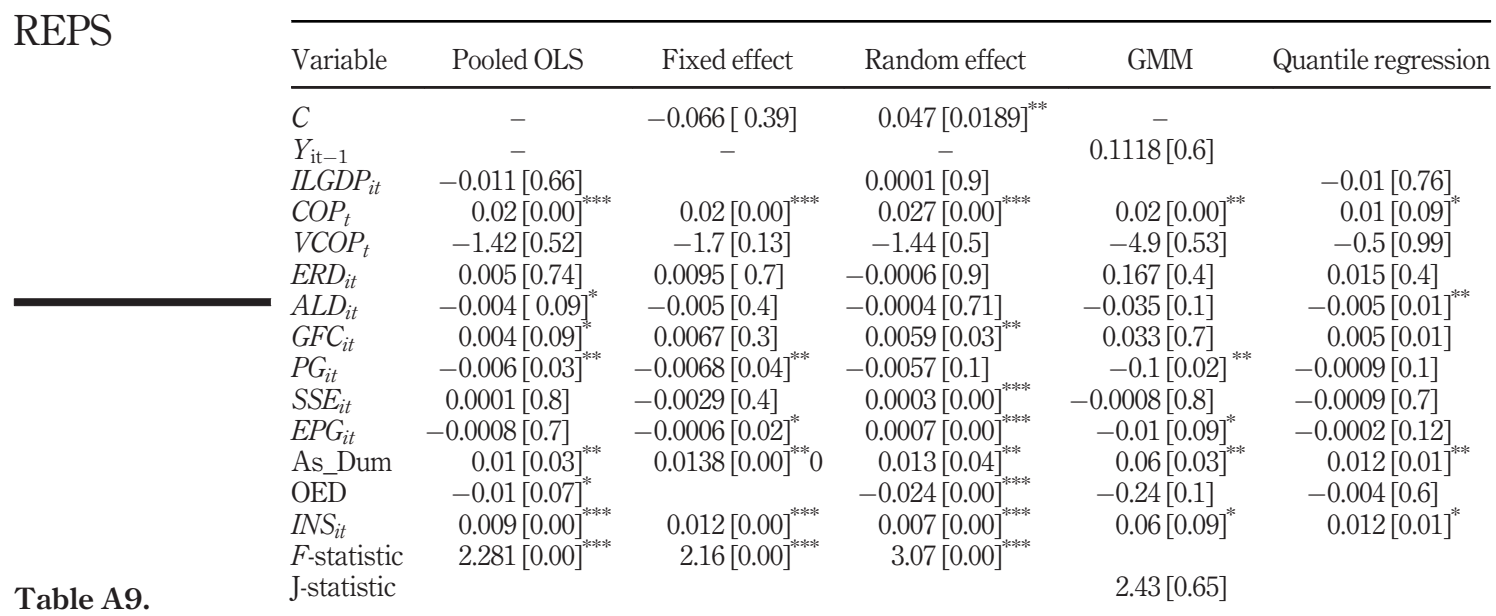

Estimates of different Notes: Numbers between are the probability of $t$-static; ${ }^{* * *}$ means the coefficient is significant with 1,5 and models with the institution

$10 \%$; ${ }^{*}$ indicate the coefficient is significant with probability 5 and $10 \%$; ${ }^{*}$ indicates significant with probability $10 \%$

Table A10.

Estimates of OLS and quantile approach for oilexports and oilimports

\section{Oil-exports}

Oil-imports

Variable Pooled OLS method Quantile regression Pooled OLS method Quantile regression

\begin{tabular}{|c|c|c|c|c|}
\hline $\mathrm{C}$ & - & - & $4.235(0.00)^{* * * *}$ & $4.23(0.00)^{* *}$ \\
\hline$I L G D P_{i t}$ & $-0.2054[0.02]^{* *}$ & $-0.2054[0.1]$ & $-0.093[0.00]^{* * * *}$ & $-0.09[0.00]^{* * *}$ \\
\hline$C O P_{t}$ & $2.79[0.00]^{* * * *}$ & $1.22[0.06]^{*}$ & $-0.117[00]^{* * * *}$ & $-0.11[0.00]^{* * *}$ \\
\hline$V C O P_{t}$ & $-0.275[0.88]$ & $-0.19[-0.86]$ & $1.8[0.07]^{*}$ & $1.8[0.07]^{*}$ \\
\hline$E R D_{i t}$ & $1.11[0.64]$ & $-0.05[0.95]$ & $0.011[0.94]^{*}$ & $0.01[0.91]$ \\
\hline$A L D_{i t}$ & $-0.55[0.00]^{* * *}$ & $-0.321[0.02]$ & $-0.048[0.1]$ & $-0.04[0.73]$ \\
\hline$G F C_{i t}$ & $1.02[0.00]^{\text {***** }}$ & $0.52[0.04]^{* *}$ & $-0.014[0.7]$. & $-0.01[0.00]^{* * * *}$ \\
\hline$P G_{i t}$ & $-0.08[0.63]$ & $-0.16[0.08]^{*}$ & $-0.11[0.00]^{* * * *}$ & $-0.11[0.00]^{* * * *}$ \\
\hline$S S E_{i t}$ & $-0.1[0.00]^{\text {**** }}$ & $-0.044[0.06]^{*}$ & $-0.0013[0.018]^{* *}$ & $-0.0008[0.68]$ \\
\hline$E P G_{i t}$ & $-0.04[0.00]^{* * * *}$ & $-0.02[0.02]^{* *}$ & $0.0008[0.00]^{* * * *}$ & $0.0084[0.00]^{3 * * *}$ \\
\hline As_Dum & $0.032[026]^{* *}$ & $0.605[0.07]^{*}$ & $0.089[0.9]^{* * *}$ & $0.089[0.00]^{* * *}$ \\
\hline$F$-statistic & $4.26[0.000]^{* * * *}$ & & $5.26[0.00]^{* *}$ & \\
\hline
\end{tabular}

Notes: Numbers between are the probability of $t$-static; ${ }^{* * *}$ means the coefficient is significant with 1,5 and $10 \%$; ${ }^{*}$ indicate the coefficient is significant with probability 5 and $10 \%$; ${ }^{*}$ indicates significant with probability $10 \%$
Table A11.

Correlation matrix between different kinds of volatility

\begin{tabular}{lll}
\hline & VCOP & SVCOP \\
\hline VCOP & 1 & 0.80657 \\
SVCOP & 0.80657 & 1
\end{tabular}

Source: Calculated by the author using Spearman rank correlation 


\begin{tabular}{|c|c|c|c|c|c|c|c|}
\hline & \multicolumn{2}{|c|}{$\begin{array}{l}\text { Estimates with a different } \\
\text { measure of oil price volatility }\end{array}$} & \multicolumn{2}{|c|}{ Estimates with removing outliers } & \multicolumn{2}{|c|}{ GDP volatility } & \multirow{2}{*}{$\begin{array}{r}\text { Oil price } \\
\text { fluctuations } \\
\text { and economic } \\
\text { growth }\end{array}$} \\
\hline & $\begin{array}{l}\text { Pooled OLS } \\
\text { method }\end{array}$ & $\begin{array}{l}\text { Quantile } \\
\text { regression }\end{array}$ & $\begin{array}{l}\text { Pooled OLS } \\
\text { method }\end{array}$ & $\begin{array}{l}\text { Quantile } \\
\text { regression }\end{array}$ & Pooled OLS & $\begin{array}{l}\text { Quantile } \\
\text { regression }\end{array}$ & \\
\hline$I L G D P_{i t}$ & $0.37[0.00]^{* * * *}$ & $0.24[0.00]^{* * * *}$ & $0.27[0.00]^{* * * *}$ & $0.045[0.00]^{* * * *}$ & $0.34[0.00]^{* * *}$ & $0.089[0.01]^{* * *}$ & \\
\hline $\mathrm{COP}_{t}$ & $0.095[0.00]^{* * * *}$ & $0.032[0.00]^{* * *}$ & $0.1[0.00]^{* * * *}$ & $0.026[0.00]^{* * *}$ & $0.07[0.00]^{* * *}$ & $0.041[0.00]^{* * * *}$ & \\
\hline$V C O P_{t}$ & $2.9[0.6]$ & $1[0.6]$ & $0.7[0.2]$ & $0.3[0.2]$ & $0.48[0.1]$ & $0.15[0.1]$ & \\
\hline$E R D_{i t}$ & $-0.03[0.5]$ & $0.0003[0.4]$ & $-0.026[0.6]$ & $-0.0013[0.9]$ & $-0.0037[0.9]$ & $-0.02[0.08]^{*}$ & \\
\hline$A L D_{i t}$ & $-0.0153[0.02]^{* *}$ & $-0.0019[0.6]$ & $-0.01[0.02]^{* *}$ & $-0.005[0.02]^{* *}$ & $-0.0022[0.6]$ & $-0.0015[0.3]$ & \\
\hline$G F C_{i t}$ & $0.012[0.28]$ & $-0.0006[0.6]$ & $0.016[0.00]^{* *}$ & $0.007[0.00]^{* * * *}$ & $0.0058[0.27]$ & $0.0026[0.09]^{*}$ & \\
\hline$P G_{i t}$ & $-0.0188[0.01]^{* *}$ & $-0.007[0.07]$ & $-0.01[0.01]^{* *}$ & $-0.0038[0.2]$ & $-0.0005[0.9]$ & $-0.0009[0.62]$ & \\
\hline$S S E_{i t}$ & $-0.0013[0.01]^{* *}$ & $-0.0006[0.8]$ & $-0.0013[0.01]^{* *}$ & $-0.0003[0.04]^{* * *}$ & $-0.0007[0.09]^{*}$ & $-0.0002[0.5]$ & \\
\hline$E P G_{i t}$ & $-0.00086[0.15]$ & $0.0032[0.92]$ & $-0.0008[0.1]$ & $0.0032[0.56]$ & $-0.0006[0.25]$ & $-0.0004[0.05]^{*}$ & \\
\hline As_Dum & $0.032[026]^{* *}$ & $0.01[0.04]^{* *}$ & $0.035[0.01]^{* *}$ & $0.016[0.00]^{* * * *}$ & $0.0136[0.3]$ & $0.0013[0.7]$ & Tal \\
\hline $\mathrm{OED}$ & $0.02[0.2]$ & $0.016[0.3]$ & $2.5[0.01]^{* *}$ & $-0.003[0.7]$ & $0.057[0.00]^{* *}$ & $0.03[0.00]^{* * * *}$ & Estimates of OIS \\
\hline $\begin{array}{l}F- \\
\text { statistic }\end{array}$ & $10.1[0.000]^{* * *}$ & & $10.36[0.000]^{* * *}$ & & $10.89[0.00]^{* * * *}$ & & $\begin{array}{r}\text { and quantile } \\
\text { approach after }\end{array}$ \\
\hline $\begin{array}{l}\text { Notes: } 1 \\
10 \% ;{ }^{* * *} \\
\text { probabili }\end{array}$ & $\begin{array}{l}\text { Numbers between } \\
\text { "indicate the coef } \\
\text { lity } 10 \%\end{array}$ & $\begin{array}{l}\mathrm{n} \text { are the probab } \\
\text { fficient is signi }\end{array}$ & $\begin{array}{l}\text { ility of } t \text {-static; } \\
\text { ficant with prol }\end{array}$ & $\begin{array}{l}\text { heans the coeffic } \\
\text { bility } 5 \text { and } 10\end{array}$ & $\begin{array}{l}\text { icient is significe } \\
0 \% \text {; *indicates }\end{array}$ & $\begin{array}{l}\text { ant with } 1,5 \text { and } \\
\text { significant with }\end{array}$ & $\begin{array}{r}\text { removing outliers } \\
\text { and different } \\
\text { volatility }\end{array}$ \\
\hline
\end{tabular}

\section{Corresponding author}

Mamdouh Abdelmoula Mohamed Abdelsalam can be contacted at: mamdouh.economist711@gmail. com

For instructions on how to order reprints of this article, please visit our website: 